\title{
Patates (Solanum tuberosum L.) Yetiştirilen Toprakların Verimlilik Durumu ve Potansiyel Besin Maddesi Sorunlarının Belirlenmesi
}

\author{
Gülen Özyazıc1 ${ }^{1 *}$, Mehmet Arif Özyazıc1², Orhan Dengiz ${ }^{3}$ \\ ${ }^{1}$ Siirt Üniversitesi, Ziraat Fakültesi, Tarla Bitkileri Bölümü, Siirt, Türkiye (ORCID: 0000-0003-2187-6733), gulenozyazici@ @otmail.com \\ 2 Siirt Üniversitesi, Ziraat Fakültesi, Tarla Bitkileri Bölümü, Siirt, Türkiye (ORCID: 0000-0001-8709-4633), arifozyazici@ hotmail.com \\ 3 Ondokuz Mayıs Üniversitesi, Ziraat Fakültesi, Toprak Bilimi ve Bitki Besleme Bölümü, Samsun, Türkiye (ORCID: 0000-0002-0458-6016), o_dengiz@ hotmail.com
}

(İlk Geliş Tarihi 6 Eylül 2020 ve Kabul Tarihi 25 Ekim 2020)

(DOI: 10.31590/ejosat.791286)

ATIF/REFERENCE: Özyazıcı, G., Özyazıcı, M.A. \& Dengiz, O. (2020). Patates (Solanum tuberosum L.) Yetiştirilen Toprakların Verimlilik Durumu ve Potansiyel Besin Maddesi Sorunlarının Belirlenmesi. Avrupa Bilim ve Teknoloji Dergisi, (20), 438-447.

$\ddot{\mathbf{O z}}$

$\mathrm{Bu}$ araştırmada, patates (Solanum tuberosum L.) yetiştirilen toprakların verimlilik durumlarının toprak analizleriyle belirlenmesi ve potansiyel bitki besin maddesi sorunlarının ortaya konması amaçlanmıştır. Bu amaçla, Türkiye'nin Karadeniz Bölgesi'nde yer alan Ordu ve Trabzon illerinde patates tarımı yapılan arazilerden 109 adet toprak örneği alınmıştır. Toprak örneklerinde bazı fiziksel (tekstür) ve kimyasal [toprak reaksiyonu $(\mathrm{pH})$, elektriksel iletkenlik (EC), kireç, organik madde, toplam azot $(\mathrm{N})$, alınabilir fosfor (P), ekstrakte edilebilir potasyum (K), kalsiyum (Ca), magnezyum (Mg), bor (B), demir (Fe), bakır $(\mathrm{Cu})$, çinko ( $\mathrm{Zn})$ ve mangan $(\mathrm{Mn})$ ] özellikleri belirlenmiştir. Araştırma sonucuna göre; toprakların ağıllıklı olarak (\% 95.42'sinin) tınlı (orta bünyeli) topraklar olduğu ve tuzluluk yönünden sorun teşkil etmediği, patates için ideal $\mathrm{pH}$ aralığındaki toprakların oranının yaklaşı \% 42.2 olduğu tespit edilmiştir. Büyük çoğunluğu az kireçli düzeyde olan patates topraklarının; \% 51.37'sinde organik madde, \% 86.24'ünde toplam N, \% 53.22'sinde alınabilir P ve \% 56.88'inde ekstrakte edilebilir K yeterli ve/veya yüksek düzeydedir. Ekstrakte edilebilir Ca ve $\mathrm{Mg}$ düzeylerinin büyük oranda iyi düzeyde olduğu araştırma topraklarının; \% 45.87'si ekstrakte edilebilir B, \% 35.78'inde ekstrakte edilebilir Zn ve \% 11.93'ünde ekstrakte edilebilir Mn çok az/az düzeydedir. Patates tarımı yapılan toprakların ekstrakte edilebilir Fe ve $\mathrm{Cu}$ içerikleri yüksek/yeterli düzeyde bulunmuştur. Ordu ve Trabzon illerinde patates tarımı yapılan alanlarda mutlaka toprak analizlerine göre gübreleme programları düzenlenmeli ve yaprak analizleri de dikkate alınarak gübreleme önerilerinde bulunulmalıdır.

Anahtar Kelimeler: Toprak verimliliği, Mineral besin maddeleri, Patates, Asit topraklar.

\section{Determination of Fertility Condition and Potential Nutrition Problems of The Potato (Solanum tuberosum L.) Grown Soils}

\begin{abstract}
In this research, it was aimed to determine the fertility status of potato (Solanum tuberosum L.) cultivated soils by soil analysis and to reveal potential plant nutrient problems. For this purpose, 109 soil samples were taken from agricultural land with potatoes in the provinces located in the Black Sea region of Turkey Ordu and Trabzon. Some physical (texture) and [chemical soil reaction (pH), electrical conductivity (EC), lime, organic matter, total nitrogen $(\mathrm{N})$, available phosphorus $(\mathrm{P})$, extractable potassium $(\mathrm{K})$, calcium $(\mathrm{Ca})$, magnesium $(\mathrm{Mg})$, boron $(\mathrm{B})$, iron $(\mathrm{Fe})$, copper $(\mathrm{Cu})$, zinc $(\mathrm{Zn})$ and manganese $(\mathrm{Mn})$ ] properties were determined in the samples. According to the results of the research; It has been determined that predominantly $(95.42 \%)$ of the soils are loamy (medium textured) soils and do not pose a problem in terms of salinity, the ratio of soils in the ideal $\mathrm{pH}$ range for potatoes is approximately $42.2 \%$. Most of potato soils are less calcareous; Organic matter at $51.37 \%$, total $\mathrm{N}$ at $86.24 \%$, obtainable $\mathrm{P}$ at $53.22 \%$ and extractable $\mathrm{K}$ at $56.88 \%$
\end{abstract}

\footnotetext{
* Sorumlu Yazar: Siirt Üniversitesi, Ziraat Fakültesi, Tarla Bitkileri Bölümü, Siirt, Türkiye, ORCID: 0000-0003-2187-6733, gulenozyazici@siirt.edu.tr
} 
are sufficient and / or high. In research soils where extractable $\mathrm{Ca}$ and $\mathrm{Mg}$ levels are mostly at good levels; $45.87 \%$ of extractable $\mathrm{B}$, $35.78 \%$ of extractable $\mathrm{Zn}$ and $11.93 \%$ of extractable $\mathrm{Mn}$ is very low / low level. Extractable Fe and Cu contents of potato cultivation soils were found to be high/sufficient. In the areas where potato cultivation is carried out in Ordu and Trabzon provinces, fertilization programs should be arranged for soil analysis and fertilization recommendations should be made by taking into account the leaf analysis.

Keywords: Soil fertility, Mineral nutrients, Potato, Acid soils.

\section{Giriș}

Günümüzde nüfus artışına paralel olarak düzensiz kentleşme ve sanayileşme, tarım arazileri üzerindeki baskıyı giderek arttırmakta; küresel ısınma ile birlikte tarım arazilerinin amaç dışı kullanımı, aşırı ve bilinçsiz gübreleme ve sulama, tarım topraklarının verimliliğinin azalmasına neden olmaktadır. $\mathrm{Bu}$ nedenle, kaybedildikleri takdirde yenilenmesi mümkün olmayan toprakların korunması, fiziksel, kimyasal ve biyolojik özellikleri dikkate alınarak kullanılması büyük önem taşımaktadır. Bu durum, tarımsal üretimde optimum ve kaliteli ürün elde edilmesinde önemli olduğu kadar, aynı zamanda sürdürülebilir toprak yönetimi ve sürdürülebilir tarım sisteminin de bir gereğidir. En uygun bir biçimde kullanıldıklarında beklenen verimi sağlayabilen toprakların (Everest ve ark., 2020), sürdürülebilir biçimde kullanılıp yönetilmesi için de toprak kaynaklarını yeterli şekilde incelemek ve izlemekle mümkündür (Özyazıcı ve ark., 2016).

İklim, topoğrafya, vejetasyon gibi faktörlere bağlı olarak çok küçük alanlarda dahi değişkenlikler gösteren toprakların özelliklerinin belirlenmesi, farklı toprak parametreleri arasındaki ilişkilerin ortaya konması, üzerinde yetişen bitki örtülerinin de verim ve kalitesi bakımından önem taşımaktadır. Türkiye'de bu amaca yönelik olarak farklı ekolojilerde büyük ve küçük ölçekli birçok çalışmalarda toprakların fiziksel ve kimyasal özellikleri ortaya konarak; çeltik tarımında (Taban ve ark., 1997), kiraz bahçelerinde (Başaran ve Okant, 2005; Yağmur ve Okur, 2011; Çelik ve Urhan, 2020), yonca tarımında (Özyazıcı ve ark., 2013), sarımsak tarımında (Akça ve ark., 2017), tahıllarda (Doğan ve Erdal, 2018; Eren, 2019), findık tarımında (Özkutlu ve ark., 2019), soya bitkisinde (Kars ve Ekberli, 2020), misir bitkisinde (Kars ve Ekberli, 2019; Ordu, 2020) potansiyel beslenme problemleri belirlenmeye çalışılmış, belirlenen toprak özellikleri doğrultusunda kullanım amacına uygun değerlendirmeler yapılarak gübreleme programlarının oluşturulmasına yönelik önemli veriler elde edilmiştir.

Dünyada besin kaynakları içerisinde ilk sıralarda yer alan patates (Solanum tuberosum L.) yetiştiriciliğinde; yumru verimini, genetik faktörlerin ve uygulanan kültürel işlemlerin yanı sıra toprak koşulları da büyük oranda etkilemektedir (Burton, 1989; Khan ve ark., 2011). Patates tarımında özellikle azot $(\mathrm{N})$, fosfor $(\mathrm{P})$ ve potasyum $(\mathrm{K})$ gibi besin elementlerinin verim ve kalitede önemli etkileri olduğu (Allison ve ark., 2001; Tunçtürk ve ark., 2004; Belachew, 2016; Zhang ve ark., 2018; Akpınar ve ark., 2019; Tatar, 2019) dikkate alındığında, patates yetiştiriciliğinin yapıldığı topraklarda bu elementler ile besin maddelerinin alımında etkili olan toprak özelliklerinin saptanması patates tarımında önem arz etmektedir.

$\mathrm{Bu}$ araştırma, Orta ve Doğu Karadeniz Bölgesi'nde hem yemeklik hem de tohumluk amaciyla ekonomik anlamda patates
(S. tuberosum L.) tarımı yapılan alanlardaki toprakların, verimlilik durumunu belirlemek ve potansiyel bitki besin maddesi sorunlarını ortaya koymak amacıyla yapılmıştır.

\section{Materyal ve Metot}

Araştırmanın materyalini, Karadeniz Bölgesi’nin Ordu ve Trabzon illerinde patates tarımının yapıldığ 1 alanlardan alınan toplam 109 adet toprak örneği oluşturmuştur. Toprak örneklerinin 49'u Ordu, 60'1 Trabzon ilinden alınmıştır (Şekil 1). Toprak örnekleri, genel kurallara uygun olarak $0-20 \mathrm{~cm}$ derinlikten Jackson (1958) tarafindan bildirildiği şekilde paslanmaz çelik kürek ile alınmıştır. Alınan toprak örnekleri laboratuvar koşullarında temiz ambalaj kâğıtlarına serilerek, taş ve bitki parçacıkları ayıklanmış, havada kurumaya bırakılmış; daha sonra kuruyan toprakların tamamı tahta tokmaklarla dövülerek 2 mm'lik çelik elekten geçirilmiş ve analizlere hazır hale getirilmiştir.

Toprak örneklerinin bünye analizleri, Bouyoucus hidrometre yöntemiyle (Bouyoucos, 1951); toprak reaksiyonu $(\mathrm{pH})$, hazırlanan saturasyon çamurunda cam elektrotlu $\mathrm{pH}$ metre ile ölçülerek (Richards, 1954), asit karakterli topraklardan alınan örneklerin $\mathrm{pH}$ analizi ise 1:2.5'luk toprak su çözeltisi kullanılarak (Sağlam, 1978); elektriksel iletkenlik (EC) değeri, saturasyon çamurundan çıkartılan ekstrakta kondaktivite cihazı ile (Richards, 1954); kireç $\left(\mathrm{CaCO}_{3}\right)$ içerikleri, Scheibler kalsimetresiyle (Çağlar, 1949); organik madde kapsamı, modifiye edilmiş Walkley Black yöntemiyle (Nelson ve Sommers, 1982); alınabilir P içeriği, alkalin ve nötr karakterli topraklar için Olsen yöntemine göre (Olsen ve ark., 1954), asit karakterli topraklar için ise Bray ve Kurtz (1945) tarafından bildirilen yönteme göre; toplam $\mathrm{N}$ analizi, modifiye Kjeldahl yöntemine göre (Jackson, 1958); ekstrakte edilebilir K, kalsiyum (Ca) ve magnezyum $(\mathrm{Mg})$ kapsamı toprakların $1 \mathrm{~N}$ amonyum asetat $(\mathrm{pH}=7.0)$ çözeltisi ile ekstrakte edilmesiyle (Anonymous, 1992); ekstrakte edilebilir bor (B) içeriği ise, topraktan sicak su ile ekstrakte edilen B miktarının azometin-H ile oluşturulan kompleksin renk yoğunluğuna dayanılarak (Wolf, 1971) belirlenmiştir. Toprakların ekstrakte edilebilir demir (Fe), bakır $(\mathrm{Cu})$, çinko $(\mathrm{Zn})$ ve mangan $(\mathrm{Mn})$ miktarları; Lindsay ve Norvell (1978) tarafından bildirildiği şekilde, toprak örneklerinin DTPA+TEA $(\mathrm{pH}=7.3)$ ile ekstrakte edildikten sonra, elde edilen süzüklerdeki $\mathrm{Fe}, \mathrm{Cu}, \mathrm{Zn}$ ve $\mathrm{Mn}$ miktarları atomik absorpsiyon spektrofotometresi (Perkin Elmer Analyst 300)'nde okunarak tayin edilmiştir.

Toprak örneklerinin kum, kil ve silt yüzdeleri kullanılarak tekstür üçgeni yardımıyla bünye sınıfları belirlenmiştir. Kimyasal analiz sonuçlarının değerlendirilmesinde sınır değerler kullanılmış olup, sınır değerlerine göre toprak örneklerinin dağılımı ve oranları hesaplanarak değerlendirmeler yapılmıştır. 


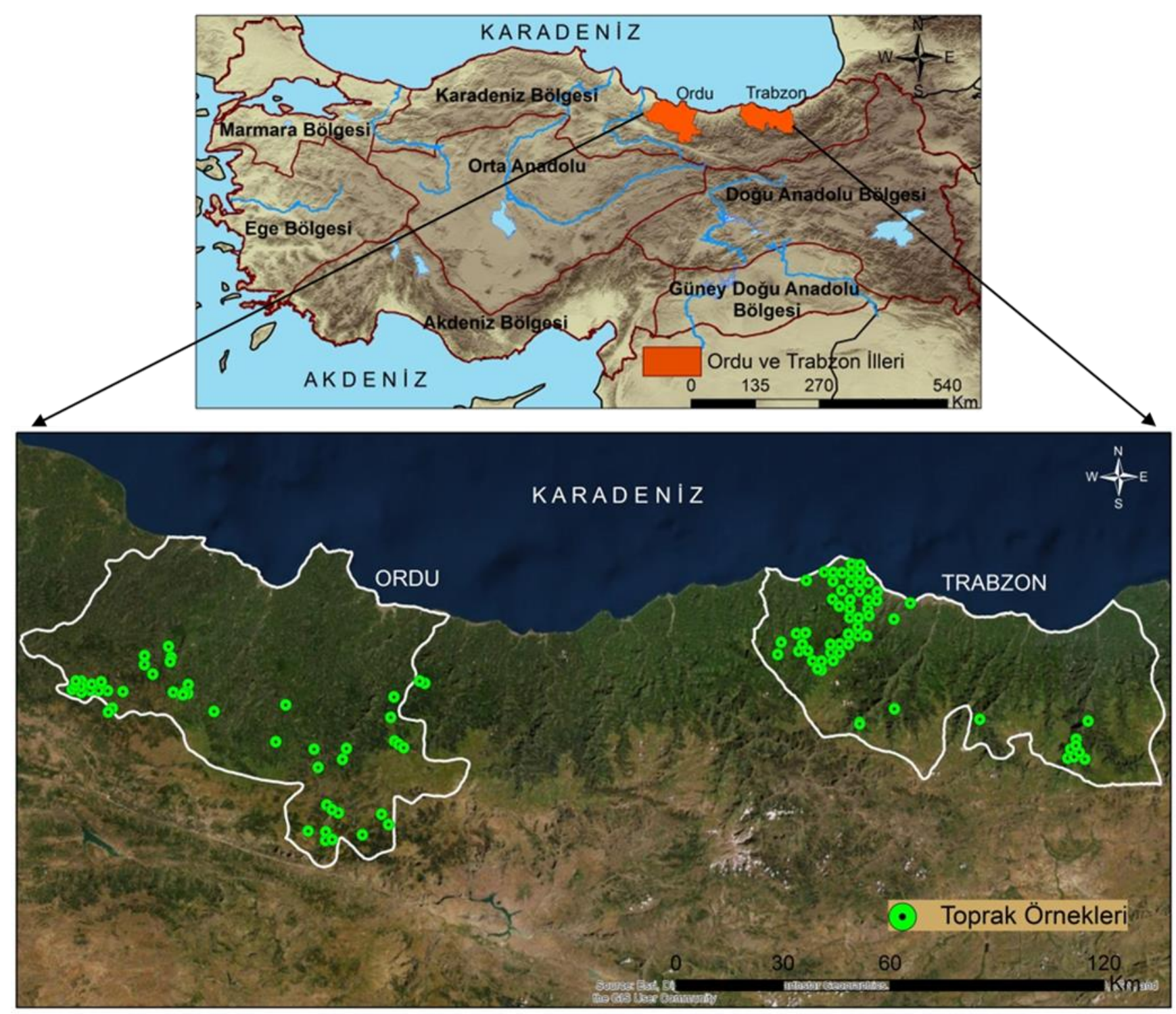

Şekil 1. Araştırma alanı lokasyon haritası, örnekleme noktaları

\section{Araştırma Sonuçları ve Tartışma}

\subsection{Toprakların Bazı Fiziksel ve Kimyasal Özellikleri}

Patates tarımı yapılan toprakların kum, kil ve silt içerikleri sirasiyla \% 23.42-83.48, \% 5.81-49.01 ve \% 7.71-38.19 arasinda değişkenlik göstermiştir (Tablo 1). Analiz sonuçlarına göre araştırma topraklarının bünye sınıfları kil (C), killi tın (CL), tın (L), tınlı-kum (LS), kumlu tın (SL) ve kumlu kil tın (SCL) olarak belirlenmiştir. Anonymous (1951) tarafından bildirilen bünye sınıflarına göre patates yetiştiriciliği yapılan toprakların \% 2.75'inin killi topraklar (C), \% 95.42'sinin tınlı (orta bünyeli) topraklar (CL, L, SL, SCL) ve \% 1.83'ünün ise kumlu (hafif bünyeli) topraklar (LS) olduğu görülmüştür (Şekil 2).

Tablo 1. Patates tarımı yapılan toprakların bazı fiziksel ve kimyasal özelliklerine ait tanımlayıcı istatistikleri $(n=109)$

\begin{tabular}{|c|c|c|c|c|c|c|c|}
\hline & \multicolumn{3}{|c|}{ Bünye (\%) } & \multirow{2}{*}{$\mathbf{p H}$} & \multirow{2}{*}{$\begin{array}{c}\text { EC } \\
(\mathrm{dS} / \mathrm{m})\end{array}$} & \multirow{2}{*}{$\begin{array}{c}\text { Kireç } \\
(\%)\end{array}$} & \multirow{2}{*}{$\begin{array}{c}\text { Organik madde } \\
(\%)\end{array}$} \\
\hline & Kum & Kil & Silt & & & & \\
\hline En düşük & 23.42 & 5.81 & 7.71 & 3.82 & 0.112 & 0.2 & 0.42 \\
\hline En yüksek & 83.48 & 49.01 & 38.19 & 7.77 & 1.953 & 50.6 & 10.68 \\
\hline Ortalama & 56.08 & 20.02 & 23.89 & 6.22 & 0.593 & 1.9 & 3.71 \\
\hline Basıklık & -0.59 & 0.21 & -0.04 & -0.95 & 4.21 & 47.33 & -0.22 \\
\hline Çarpıklık & -0.18 & 0.79 & -0.50 & -0.45 & 1.89 & 6.53 & 0.66 \\
\hline Ortanca & 55.27 & 17.26 & 24.61 & 6.53 & 0.53 & 0.47 & 3.01 \\
\hline Standart sapma & 12.30 & 9.65 & 6.06 & 1.07 & 0.37 & 5.98 & 2.12 \\
\hline Varyans & 151.23 & 93.12 & 36.76 & 1.15 & 0.13 & 35.74 & 4.47 \\
\hline Değişsim katsayısı & 21.93 & 48.19 & 25.37 & 17.26 & 61.68 & 311.35 & 57.00 \\
\hline
\end{tabular}


Fiziki yapı bakımından patates için ideal topraklar, yumuşak, kabarmış, gevşek yapılı ve iyi havalandırılmış topraklardır. Bu toprakların daha çok kumlu tın, siltli tın ve tın arasında değişen topraklar olduğu bildirilmektedir (Esendal, 1990; Anonymous, 2020a). Bu duruma göre, incelenen toprakların büyük çoğunluğunun patates yetiştiriciliği için uygun tekstüre sahip olduğu söylenebilir. Kil oranının yüksek olduğu verimli topraklarda patatesten iyi verim alınabilir; ancak, killi topraklarda patates yumruları iyi gelişemez. Esendal (1990), orta derecede ağır topraklarda iyi sonuç alabilmek için topraklara yeşil gübreleme uygulamasının önerildiğini bildirmektedir. Afyonkarahisar ili Dinar ilçesi patates ekim alanlarından alınan toprak örneklerinin \% 87.14'ünün killi tın bünyeli olduğu (Çetin ve Eraslan, 2015); İzmir ili Ödemiş ilçesinde patates yetiştirilen toprakların \% 94.88'lik kısmının tın bünyeli topraklar olduğu (Parlak, 2016) rapor edilmiştir.

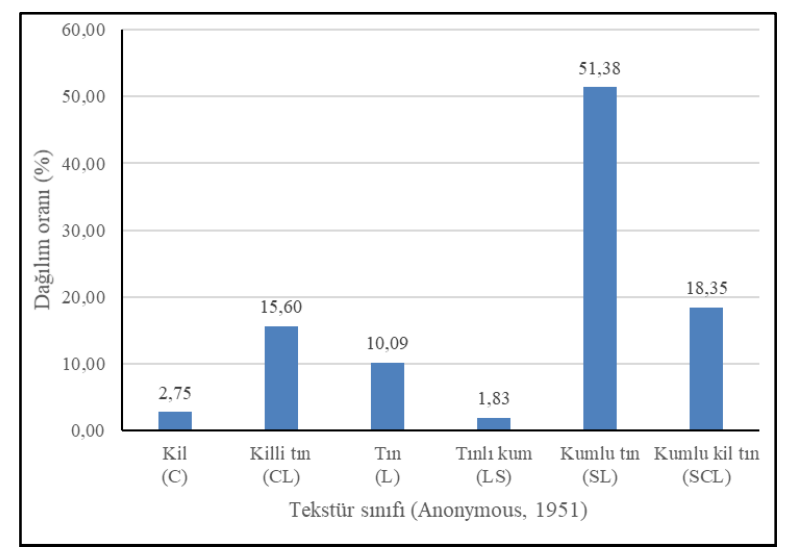

Şekil 2. Patates Tarımı Yapılan Toprakların Tekstür Sinıflarına Göre Dă̆llımları $(n=109)$

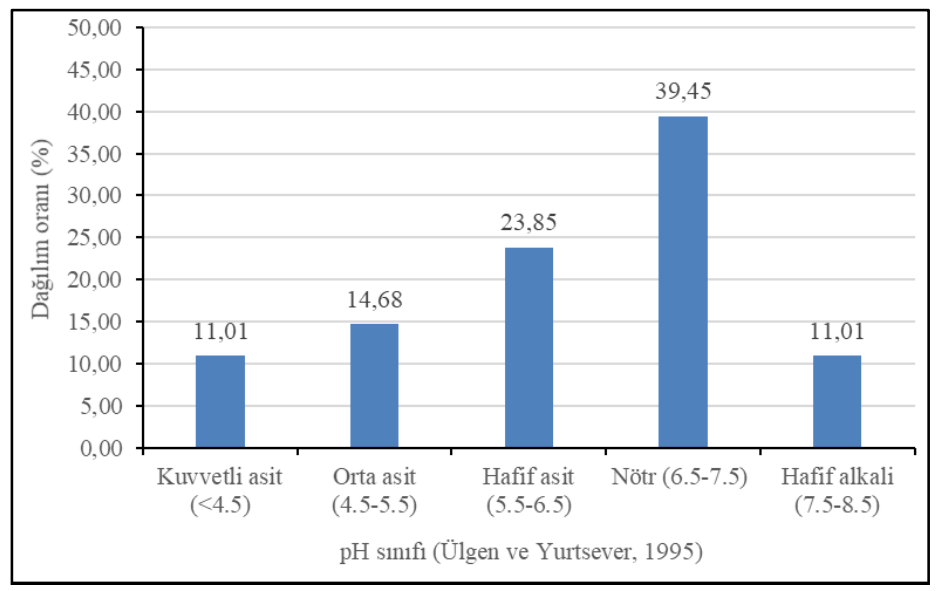

Şekil 3. Patates Tarımı Yapılan Topraklarda pH ve EC Değerlerinin Dă̆ılımı $(n=109)$

Patates tarımının yapıldığı tarım alanlarından alınan toprak örneklerinin kireç kapsamlarının \% 0.2-50.6 arasında değiştiği belirlenmiştir (Tablo 1). Şekil 4'ten de görüleceği üzere, topraklar kireç kapsamları yönünden az kireçli ile çok fazla kireçli arasında dağılım gösterdiği; toprakların \% 76.15'inin az kireçli, \% 16.51'inin kireçli, \% 5.51'inin orta kireçli ve \% 1.83'ünün ise çok fazla kireçli olduğu saptanmıştır. Özellikle düşük $\mathrm{pH}$ değerlerinin bulunduğu topraklarda, toprak analiz sonuçlarına bağlı olarak kireçlemenin yapılması patates verimi
Araştırmada incelenen toprak örneklerinin $\mathrm{pH}$ değerlerinin 3.82-7.77 arasında değiştiği belirlenmiştir (Tablo 1). Toprak örneklerinin Ülgen ve Yurtsever (1995) tarafindan bildirilen sınır değerlerine göre dağılımı incelendiğinde; \% 11.01'inin kuvvetli asit, \% 14.68'inin orta asit, \% 23.85'inin hafif asit, \% 39.45'inin nötr, \% 11.01'inin ise hafif alkali tepkimeye sahip olduğu saptanmıştır (Şekil 3). Patates tarımında iyi verim alınması ve özellikle uyuz hastalıklarının zarar yapmaması için toprak reaksiyonu asit olmalıdır (Esendal, 1990). Patates tarımında ideal pH aralığını; İncekara (1973) 5.4-7.5, Jane (2016) ve Anonymous (2020b) 5.5-6.0, Anonymous (2020a) 5.2-6.4, Mugo ve ark. (2020) 5.5-7.0 arasında bildirmektedirler. Metcalfe ve Elkins (1980) ve Anonymous (2020b), toprak pH değerinin 4.86.1 aralığının dişında olması durumunda verimin düştüğünü ifade etmiştir. Jane (2016), patates bitkisi asit topraklara toleranslı olmasına rağmen, bitki besin elementlerinin alınabilirliği açısından pH'nın 6-6.5 aralığına yükseltilmesinin faydalı olacağını belirtmektedir. Kenya'da patates yetiştirilen toprakların $\mathrm{pH}$ değerinin 5.5'in altında ve genellikle $\mathrm{pH}=4-5$ aralığının daha yaygın olduğu bildirilmektedir (Kiiya ve ark., 2006). Araştırmacılar pH'nın 5.5'in altında olması halinde $\mathrm{K}, \mathrm{N}$, $\mathrm{P}$, kükürt (S), Ca ve $\mathrm{Mg}$ alımının sınırlanacağını, alüminyum (Al), Mn, B, Fe, Cu ve $\mathrm{Zn}$ seviyelerinin yükseleceğini (Recke ve ark., 1997; Kanyanjua ve Agaya, 2006); patates veriminde daha da fazla verim düşüklüğüne neden olan düşük toprak $\mathrm{pH}$ 's1 probleminin besin dengesizliklerine de yol açmasının ihtimal dahilinde olduğunu (Janssens ve ark., 2013) rapor etmişlerdir. Araştırmamızda, Ordu ve Trabzon illerinde patates yetiştiriciliğinin yapıldığı toprakların yaklaşık \% 42.2'sinin patates için uygun $\mathrm{pH}$ aralığında $(\mathrm{pH}=5.5-7.0)$ olduğu söylenebilir. Patates tarımında sorun teşkil eden kuvvetli ve orta asit topraklarda, toprak analizlerine göre kireç; hafif alkalin topraklarda ise, kükürt uygulaması önem arzetmektedir.

İncelenen toprakların EC değerleri 0.112-1.953 dS/m arasında değişmekte olup (Tablo 1), patates tarımı yapılan topraklarda tuzluluk problemi bulunmamaktadır (Şekil 3). Benzer bulgular Parlak (2016) tarafından da rapor edilmiştir.

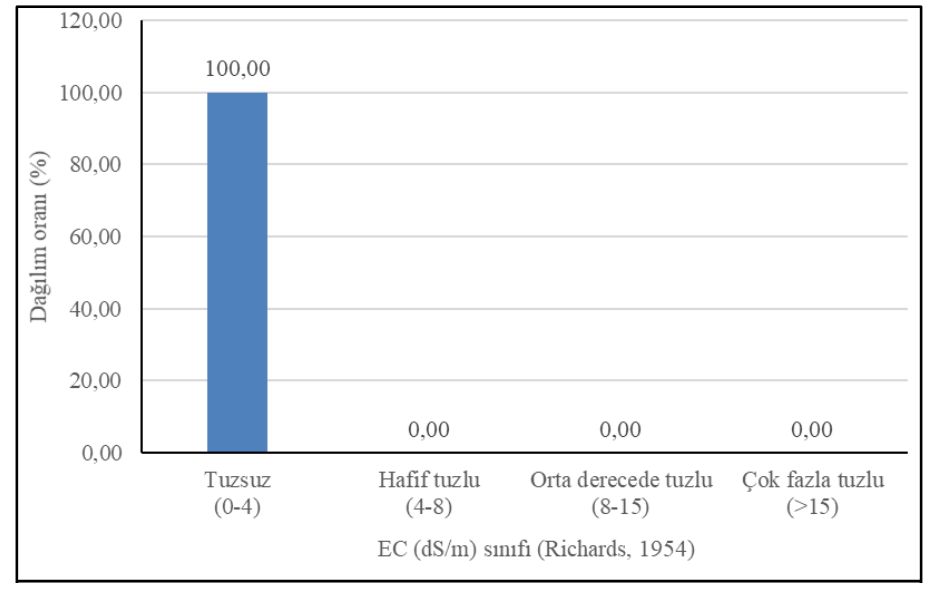

bakımından mutlaka gereklidir. Araştırmamız bulgularına benzer şekilde Ödemiş'te patates yetiştirilen toprakların \% 84.62'sinin az kireçli, \% 15.38'inin ise kireçli sınıfta yer aldığı belirlenmiştir (Parlak, 2016). Afyonkarahisar-Dinar ilçesi patates ekim alanlarında ise analiz yapılan toprak örneklerinin \% 72.9'unun orta kireçli ve \% 25.7'sinin fazla kireçli olduğu tespit edilmiştir (Çetin ve Eraslan, 2015). 
Patates yetiştirilen tarım topraklarının organik madde içeriklerinin \% 0.42-10.68 arasında değişkenlik göstermiştir (Tablo 1). Ülgen ve Yurtsever (1995)'e göre yapilan sinıflandırmada analizi yapılan toprak örneklerinin \% 26.61'inin çok az ve az, $\% 22.02$ 'sinin orta ve \% 51.37'sinin ise organik madde yönünden iyi ve yüksek sınıfında yer aldığı saptanmıştır (Şekil 4). Mugo ve ark. (2020), patates tarımında toprak organik maddesinin, toprak $\mathrm{pH}$ 'sindan sonra sürdürülebilir besin maddelerinin yönetiminde ikinci derecede önemli faktör olduğunu vurgulamışlardır. Toprakta bitki besin maddelerinin yarayışlılığında etkili olan organik maddenin yetersiz olduğu alanlarda; ahır gübresi, kompost, hümik asit gibi toprak organik maddesini arttıran uygulamaların yapılması önerilebilinir. Patates yetiştirilen topraklarda yapılan araştırmalarda farklı sonuçlar elde edilmiştir. Örneğin, Afyonkarahisar yöresinde incelenen toprakların organik madde kapsamlarının \% $0.52-\% \quad 2.87$ arasında değiştiği ve incelenen toprakların \% 5.7'sinin çok az, \% 81.44'unun az ve \% 12.86'sının orta düzeyde organik madde içerdiği (Çetin ve Eraslan, 2015), İzmir yöresinde ise incelenen toprakların tamamının çok az ve az düzeyde organik madde kapsadığı (Parlak, 2016) saptanmıştır.
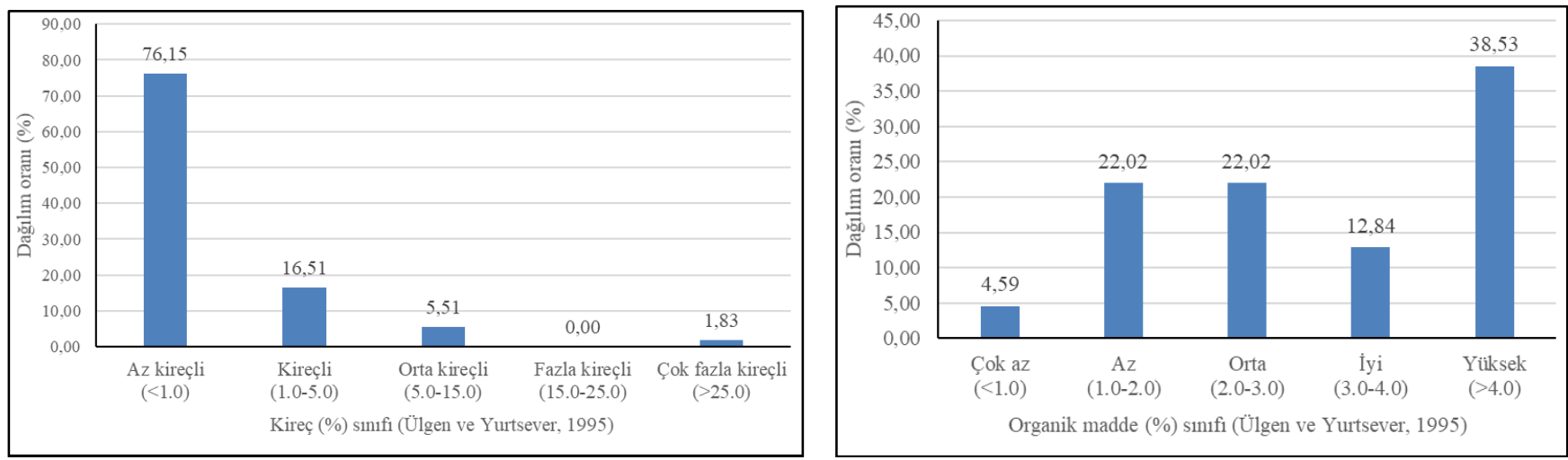

Şekil 4. Patates Tarımı Yapılan Topraklarda Kireç ve Organik Madde Miktarlarının Dă̆ılımı (n= 109)

\subsection{Toprakların Besin Maddesi İçerikleri}

Patates tarımı yapılan toprakların toplam $\mathrm{N}$ kapsamları \% 0.022-0.689 arasında değişmektedir (Tablo 2). Şekil 5'ten de görüldüğü üzere, Anonymous (1990)'a göre yapılan sinıflandirma sonucunda, incelenen toprakların toplam $\mathrm{N}$ kapsamlarının büyük çoğunluğunun (\% 86.24'ünün) yeterlifazla-çok fazla düzeyde olduğu anlaşılmıştır. Patates azotu en iyi şekilde değerlendiren bir bitki olup; $\mathrm{N}$, patateste nişastanın teşekkül etmesi için gerekli olan ve yumru verimini etkileyen önemli besin elementlerinden biridir (Westermann ve ark., 1988; Esendal, 1990; Muleta ve Aga, 2019; Koch ve ark., 2020).
Toplam N toprakta değişkenlik gösteren bir element olup, toprak azotunun kaynağını toprak organik maddesi veya humus oluşturur (Rourke, 1985; Bilen ve Sezen, 1993). Bu nedenle toprak organik maddesine bağlı olarak azotlu gübre uygulanmalıdır. Patates yetiştirilen alanlarda yapılan çalışmalarda, Çetin ve Eraslan (2015) toprakların N bakımından $\%$ 27.14'ünün az, \% 50'sinin yeterli, \% 22.86'sının fazla durumda olduğunu; Parlak (2016) toprakların toplam N miktarlarının \% $0.03-\% \quad 0.95$ arasında değiştiğini, toprakların toplam $\mathrm{N}$ yönünden \% 20.51'inin çok az, \% 74.36'sının az ve \% 5.13'ünün yeterli düzeyde azot içerdiğini saptamışlardır.

Tablo 2. Patates tarımı yapılan toprakların besin elementi içeriklerine ait tanımlayıcı istatistikleri $(n=109)$

\begin{tabular}{|c|c|c|c|c|c|c|c|c|c|c|}
\hline & \multirow{2}{*}{$\begin{array}{c}\text { Toplam } \mathrm{N} \\
(\%)\end{array}$} & \multirow{2}{*}{$\begin{array}{l}\text { Alınabilir P } \\
\left(\operatorname{kg} \mathrm{P}_{2} \mathrm{O}_{5} / \text { da }\right)\end{array}$} & \multicolumn{8}{|c|}{ Ekstrakte edilebilir makro ve mikro elementler (ppm) } \\
\hline & & & $\mathbf{K}$ & $\mathbf{C a}$ & Mg & $\mathbf{B}$ & $\mathbf{F e}$ & $\mathbf{C u}$ & Zn & Mn \\
\hline En düşük & 0.022 & 0.1 & 42 & 435 & 41 & 0.33 & 5.41 & 0.21 & 0.11 & 4.61 \\
\hline En yüksek & 0.689 & 113.2 & 832 & 10740 & 2681 & 3.67 & 209.87 & 22.27 & 9.28 & 130.96 \\
\hline Ortalama & 0.205 & 20.1 & 278 & 4412 & 719 & 1.17 & 46.69 & 3.24 & 2.03 & 34.87 \\
\hline Basıklık & 2.17 & 4.38 & 0.25 & -0.43 & 0.55 & 2.13 & 2.66 & 34.62 & 2.22 & 2.56 \\
\hline Çarpıklık & 1.16 & 2.10 & 0.91 & 0.37 & 1.33 & 1.25 & 1.42 & 4.64 & 1.77 & 1.42 \\
\hline Ortanca & 0.18 & 11.12 & 233.00 & 4415.00 & 416.54 & 1.02 & 35.74 & 2.76 & 1.03 & 28.51 \\
\hline StdS & 0.11 & 24.85 & 183.50 & 2613.05 & 686.93 & 0.60 & 38.17 & 2.42 & 2.34 & 22.45 \\
\hline Varyans & 0.01 & 617.56 & 33671.83 & 6828006.05 & 471879.21 & 0.37 & 1456.88 & 5.88 & 5.49 & 503.83 \\
\hline DK & 55.65 & 123.67 & 66.00 & 59.22 & 95.57 & 51.85 & 81.76 & 74.72 & 115.32 & 64.38 \\
\hline
\end{tabular}

StdS: Standart sapma, DK: Değişim katsayısı, n: örnek sayısı

Patates yetiştirilen toprakların alınabilir $\mathrm{P}$ kapsamlarının 0.1-113.2 $\mathrm{kg} \mathrm{P}_{2} \mathrm{O}_{5} /$ da arasında değiştiği belirlenmiştir (Tablo 2). Topraklar alınabilir P kapsamları yönünden Ülgen ve Yurtsever (1995)'e göre sınıflandırıldığında; \% 37.61'inin çok az ve az, \% 9.17'sinin orta, \% 53.22'sinin yüksek ve çok yüksek seviyede P içerdiği görülmüştür (Şekil 5). Nispeten yüzlek kök sistemi nedeniyle patates, diğer tarla bitkilerinden daha çok fosfora ihtiyaç duyar (Tindall ve ark., 1993; Anonymous, 2020c).
Patates tarımında P, yumru sayısında ve yumru veriminde etkili olmaktadır (Allison ve ark., 2001; Kavurmac1, 2008; Zelalem ve ark., 2009; Fernandes ve ark., 2015). Patates tarımında fosforun önemli bir besin maddesi olduğu dikkate alındığında, Ordu ve Trabzon yöresinde patates dikim öncesi mutlaka toprak analizlerinin yapılması ve eksikliği görülen alanlarda tavsiye edilen miktar ve gübre cinsi ile fosforlu gübre uygulamalarının yapılması önem taşımaktadır. 

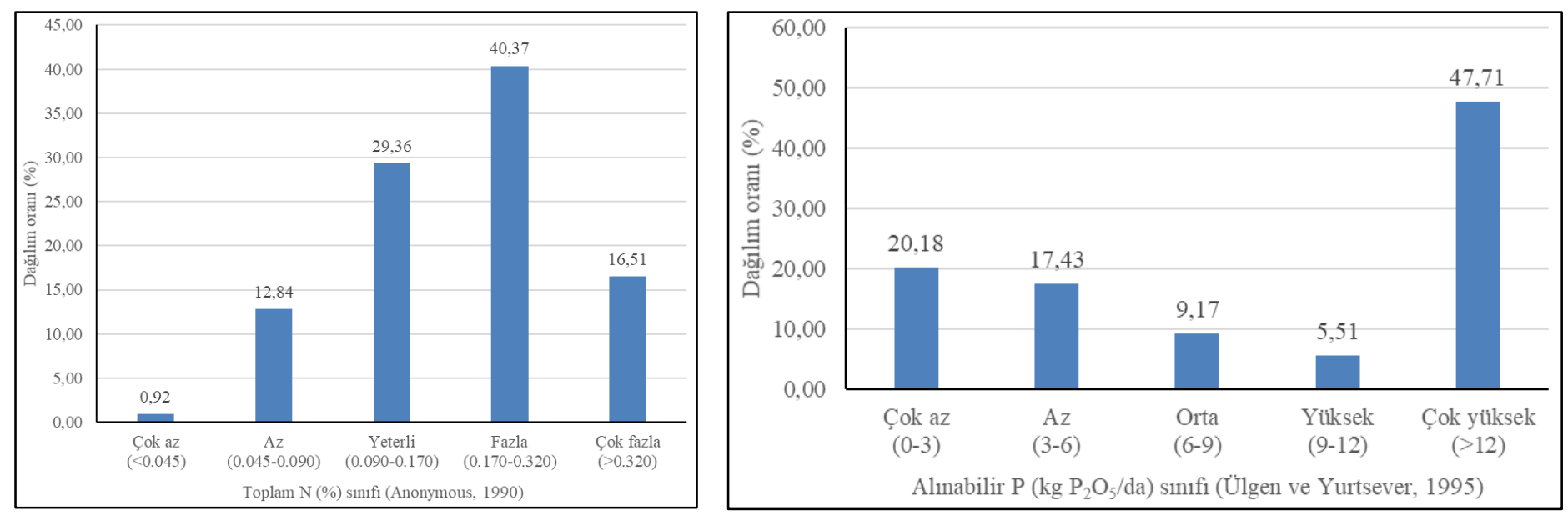

Şekil 5. Patates Tarımı Yapılan Topraklarda Toplam N ve Alınabilir P Miktarlarının Dă̆ılımı $(n=109)$

Analizi yapılan toprak örneklerinin ekstrakte edilebilir $\mathrm{K}$ kapsamlarının 42-832 ppm arasında değiştiği görülmektedir (Tablo 2). Toprak örneklerinin \% 30.28'inin çok düşük ve düşük, \% 12.84'ünün orta, \% 56.88'inin ise iyi, yüksek ve çok yüksek düzeyde K içerdiği saptanmıştır (Şekil 6). Potasyum, patates bitkisinde genellikle yumru verimi ve kalitesinde etkili olan ve patates tarafindan topraktan en fazla sömürülen bir besin elementidir (Esendal, 1990; Abd El-Latif ve ark., 2011; Zhang ve ark., 2018; Anonymous, 2020c). Orta düzeydeki K miktarı da dikkate alındığında Ordu ve Trabzon yöresi patates tarımı yapılan toprakların yaklaşık \% 43'lük bir bölümünde potasyumun düşük düzeyde olduğu görülmektedir. Bu nedenle istenilen kalitede patates yumrusu elde etmek için toprak analizine göre potasyum gübrelemesi yapılmalıdır. Afyonkarahisar ilinde yapılan araştırmada, patates topraklarının değişebilir K içeriklerinin 107.5-602.6 ppm arasında değiştiği ve toprakların \% 54.29'unda potasyumun yeterli, \% 42.86'sında fazla düzeyde olduğu (Çetin ve Eraslan, 2015); İzmir ilinde yapılan araştırmada ise toprakların alınabilir $\mathrm{K}$ kapsamlarının 30.29 ppm ile 177.79 ppm arasında değiştiği ve incelenen toprakların \% 87.18'inde potasyumun yeterli düzeyde olduğu (Parlak, 2016) rapor edilmiştir. Bagherzadeh ve ark. (2018), İran'ın kuzey doğusunda yer alan patates üretim alanlarında yaptıkları araştırmada, toprakların alınabilir $\mathrm{K}$ kapsamlarının 92.24-450.15 ppm arasında değiştiğini bildirmişlerdir.

Tablo 2'den de görüleceği üzere patates tarımı yapılan toprakların ekstrakte edilebilir $\mathrm{Ca}$ ve $\mathrm{Mg}$ miktarları surasıyla 435-10740 ppm ve 41-2681 ppm arasında değişkenlik göstermiştir. Loue (1968) tarafından bildirilen sınıflandırmaya göre incelenen tarım alanlarının ekstrakte edilebilir $\mathrm{Ca}$ ve $\mathrm{Mg}$ yönünden büyük çoğunluğunun iyi düzeyde olduğu belirlenmiştir (Şekil 6 ve 7). Afyonkarahisar (Çetin ve Eraslan, 2015) ve İzmir ili (Parlak, 2016) patates tarımı yapılan topraklarda da araştırmamız bulgularına benzer şekilde, toprakta alınabilir $\mathrm{Ca}$ ve $\mathrm{Mg}$ miktarlarının incelenen toprak örneklerinin önemli bir kısmında yeterli düzeyde olduğu belirlenmiştir.
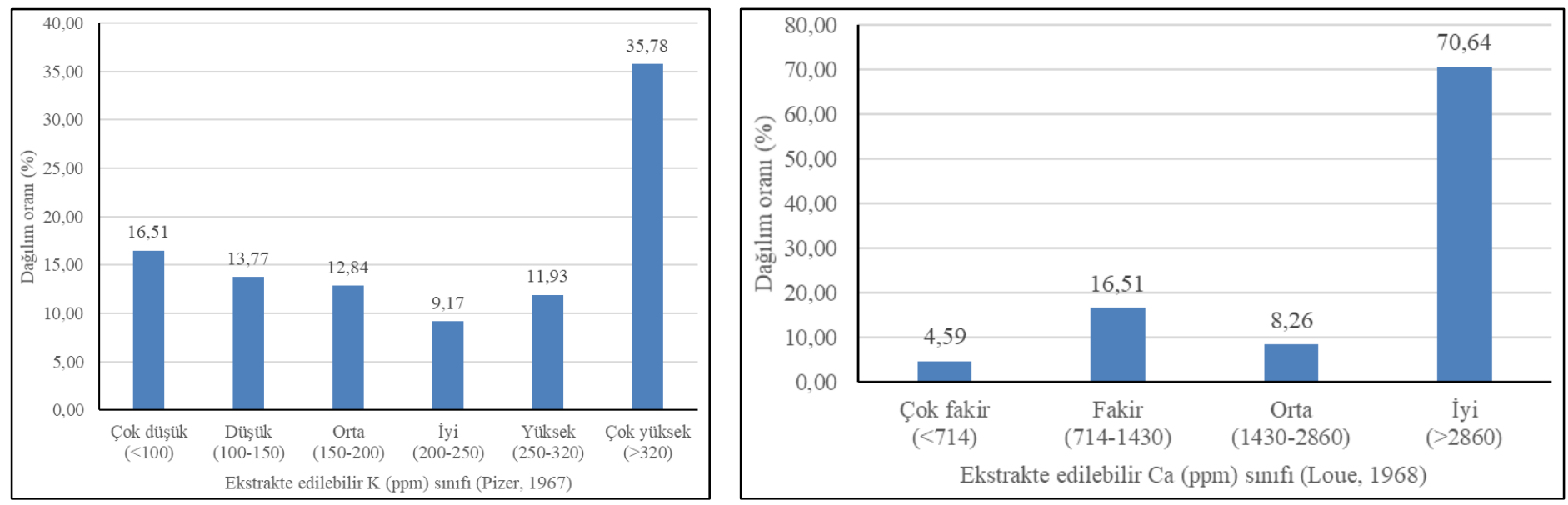

Şekil 6. Patates Tarımı Yapılan Topraklarda Ekstrakte Edilebilir K ve Ca Miktarlarının Dă̆llımı (n= 109) 

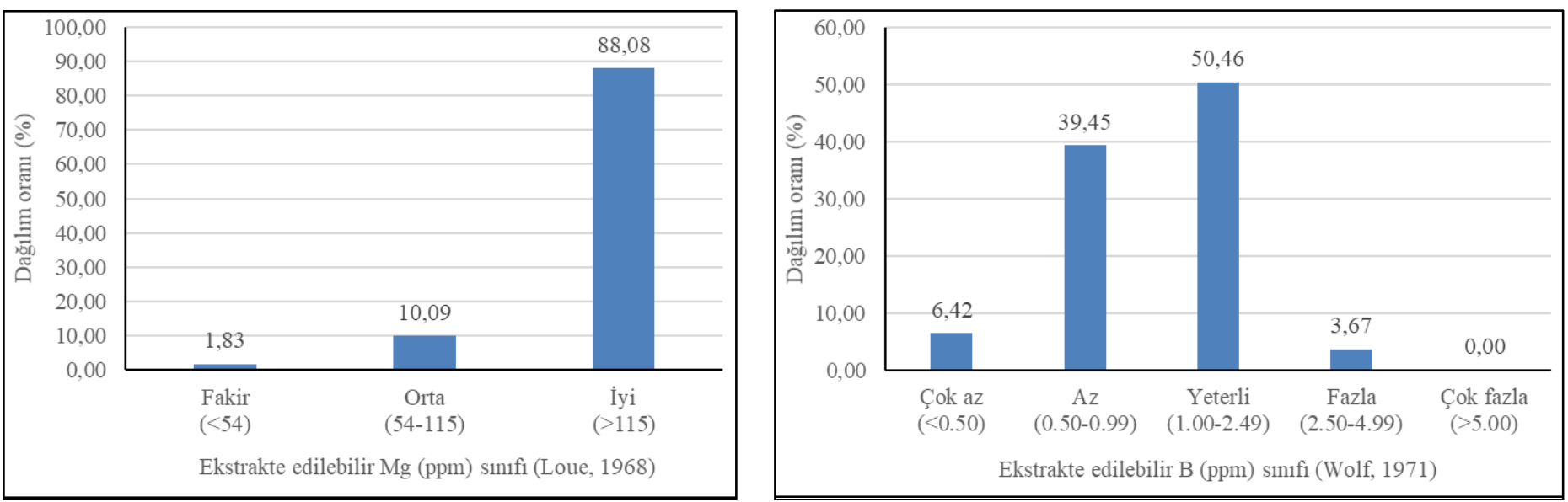

Şekil 7. Patates Tarımı Yapılan Topraklarda Ekstrakte Edilebilir Mg ve B Miktarlarının Dağılımı (n=109)

Patates tarımı yapılan toprakların ekstrakte edilebilir B içerikleri 0.33-3.67 ppm arasında değişiklik göstermiştir (Tablo 2). Wolf (1971)'a göre yapılan sinıflandırmada; toprak örneklerinin \% 45.87'si çok az ve az düzeyde bor içerirken, \% 50.46'sının yeterli, \% 3.67'sinin ise fazla düzeyde ekstrakte edilebilir B kapsadığı belirlenmiştir (Şekil 7). Toprakta borun alınabilirliğinde toprak pH'sı önemli ölçüde etkilidir. Düşük pH'da bor bileşiklerinin çoğu çözünür halde bulunmaktadır. Ancak, düşük $\mathrm{pH}$ değerine sahip kum oranı yüksek hafif topraklarda B, yüksek yağış şartlarına bağlı olarak toprak profilinden süzülerek kaybolur (Sarkar ve ark., 2007; Muthanna ve ark., 2017). Yağış miktarı yüksek Ordu ve Trabzon ili tarım topraklarında B noksanlığının muhtemel sebepleri arasında bu durumun etkili olduğu söylenebilir. Borun patateste filizlenme, bitki büyümesi ve yumru gelişiminde rol oynadığı (Trehan ve Grewal, 1981; Muthanna ve ark., 2017; Lenka ve ark., 2020) düşünülürse, B noksanlığının görüldüğü patates alanlarında, gübreleme programlarına borun dahil edilmesi önemli bir kazanım olacaktır. Kenya'nın Meru ve Nyandarua bölgelerindeki patates tarımının yapıldığı topraklarda incelenen toprak örneklerinin \% 80'den fazlasında B kritik seviyenin altında bulunmuştur (Mugo ve ark., 2020).

Toprakların ekstrakte edilebilir $\mathrm{Fe}, \mathrm{Cu}, \mathrm{Zn}$ ve $\mathrm{Mn}$ kapsamlarının sırasıyla; 5.41-209.87 ppm, 0.21-22.27 ppm, 0.119.28 ppm ve 4.61-130.96 ppm arasında değişkenlik göstermiştir (Tablo 2). İncelenen toprakların ekstrakte edilebilir $\mathrm{Fe}$ ve $\mathrm{Cu}$ içeriklerinin tamamı yüksek/yeterli düzeyde olduğu saptanmıştır
(Şekil 8). Ekstrakte edilebilir Zn bakımından örneklerin \% 35.78 'inin çok az ve az, \% 40.37'sinin yeterli ve \% 23.85'inin ise fazla ve çok fazla; ekstrakte edilebilir Mn yönünden ise \% 11.93'ünün az, \% 67.89'unun yeterli ve \% 20.18'inin ise fazla düzeyde olduğu tespit edilmiştir (Şekil 9). Çinko ve Mn noksanlıklarının görüldüğü alanlarda, gübreleme programlarına Zn ve manganın dâhil edilmesinde yarar bulunmaktadır. Çünkü patates tarımında üzerinde durulması gereken öncelikli besin maddeleri makro elementler olmasına rağmen, $\mathrm{Fe}, \mathrm{Cu}, \mathrm{Zn}, \mathrm{Mn}$ ve $\mathrm{B}$ gibi mikro besin elementleri de verim ve kalite üzerinde önemli etkilere sahiptir (Demir ve Çalışkan, 2017; Moinuddin ve ark., 2017). Nitekim Al-Fadhly (2016) Zn+Mn uygulamasının patateste yumru ağırlığını, ortalama bitki başına yumru verimini ve toplam yumru verimini; Al Fadlly ve ark. (2020), Zn+Mn uygulamasının patateste gövde sayısını, bitki boyunu ve kuru ağırlığını arttırdığını bildirmişlerdir. Afyonkarahisar ili patates topraklarında ise, incelenen örneklerin \% 70'inde $\mathrm{Fe}$ orta ve $\mathrm{Zn}$ çok az/az, \% 97.15'inde $\mathrm{Mn}$, tamamında da $\mathrm{Cu}$ yeterli düzeyde olduğu saptanmıştır (Çetin ve Eraslan, 2015). İzmir ili Ödemiş ilçesi patates topraklarında alınabilir demirin incelenen toprak örneklerinin \% 76.92'sinde, $\mathrm{Cu}$ örneklerin tamamında, $\mathrm{Zn} \%$ 61.54'ünde ve Mn ise \% 43.59'unda yeterli düzeyde olduğu rapor edilmiştir (Parlak, 2016). Bagherzadeh ve ark. (2018), İran'ın kuzey doğusunda yer alan patates üretim alanlarında yaptıkları araştırmada, toprakların alınabilir $\mathrm{Fe}$ ve $\mathrm{Mn}$ içeriklerinin sırasıyla $2.68-5.90 \mathrm{ppm}$ ve 4.02-12.10 ppm arasında değiştiğini bildirmişlerdir.
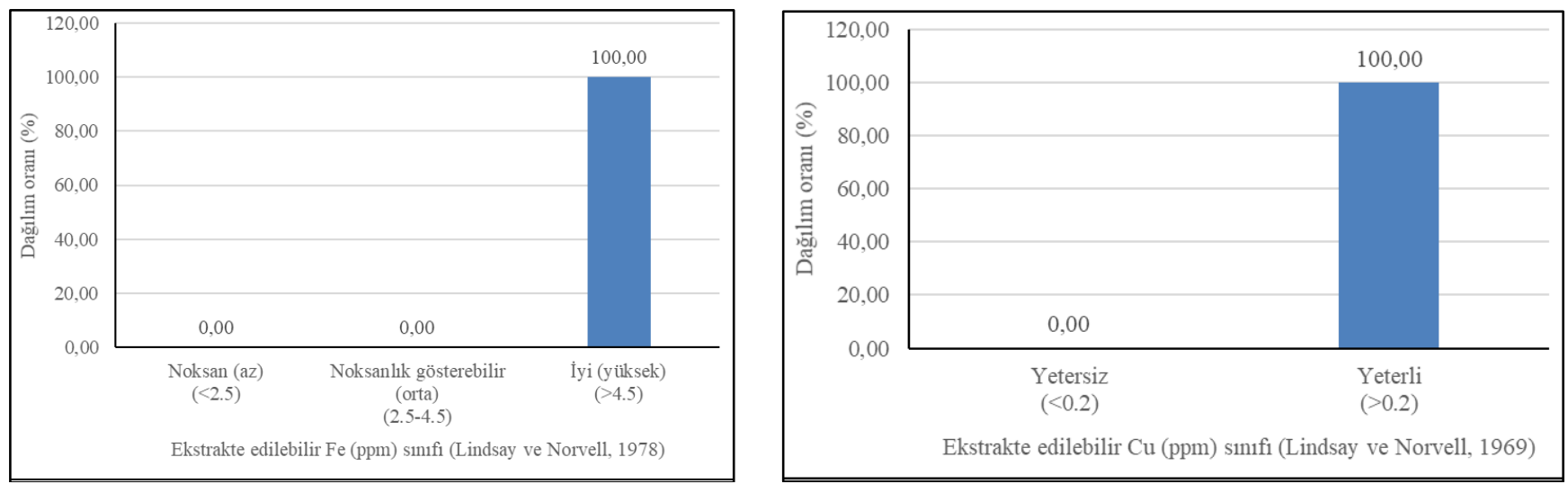

Şekil 8. Patates Tarımı Yapılan Topraklarda Ekstrakte Edilebilir Fe ve Cu Miktarlarının Dağılımı (n= 109) 

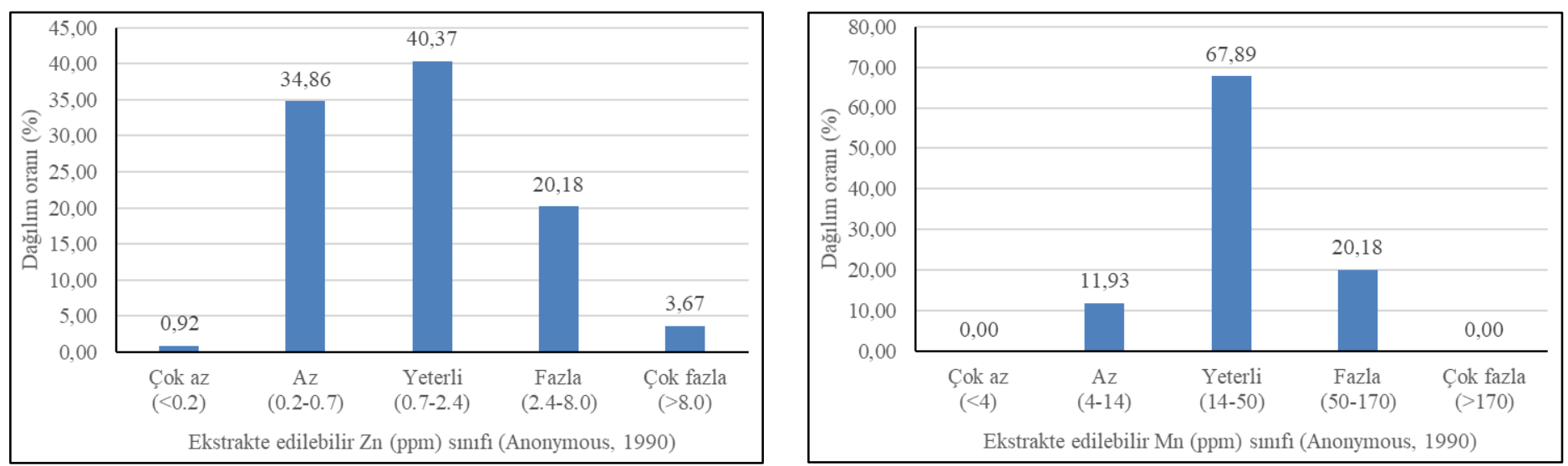

Şekil 9. Patates Tarımı Yapılan Topraklarda Ekstrakte Edilebilir Zn ve Mn Miktarlarının Dağıllımı (n=109)

\section{Sonuç}

Ordu ve Trabzon illerinde patates yetiştirilen toprakların çok büyük bir çoğunluğunu (\% 95.42) bitki gelişimi yönünden iyi özelliklere sahip tınlı (orta bünyeli) bünyeli topraklar oluşturmaktadır. Tuzluluk yönünden sorunu bulunmayan ve kireç kapsamları büyük çoğunluğunda az kireçli düzeyde olan topraklarda, toprak reaksiyonu yönünden patates verim ve kalitesini sınırlandıran alanlarda mutlaka kireç ve/veya gerektiğinde kükürt uygulaması yerinde olacaktır. Araştırma yapılan patates topraklarında organik madde içerikleri incelenen toprak örneklerinin \% 48.63'ünde çok az-orta düzeyleri arasında yer almaktadır. $\mathrm{Bu}$ alanlarda organik madde seviyesini artıracak toprak düzenleyicilerin kullanımı, yeşil gübre ve ekim nöbeti uygulamalarının yaygınlaştırılması şeklinde bir dizi önlemlerin alınması gereklidir. Temel bitki besin maddeleri olan N, P, K yönünden mutlaka dikim öncesi toprak analizlerinin yapılması ve patates tarımında son derece önemli olan bu elementler yönünden eksikliği görülen alanlarda gübreleme programlarının toprakların diğer özellikleri de dikkate alınarak düzenlenmesi, bitki verim ve kalitesi açısından önemli olduğu kadar çevre kirliliği oluşmaması açısından da önem taşımaktadır. İncelenen toprakların ekstrakte edilebilir $\mathrm{Ca}, \mathrm{Mg}, \mathrm{Fe}$ ve $\mathrm{Cu}$ yönünden bir olumsuzluk bulunmamaktadır. Ekstrakte edilebilir B, $\mathrm{Zn}$ ve $\mathrm{Mn}$ noksanlığı söz konusu olan alanlarda adı geçen bu mikro elementler yönünden toprak ve/veya yaprak gübrelemesinin yapılmas1 yerinde olacaktır. Ordu ve Trabzon illerinde patates tarımı yapılan alanlarda mutlaka toprak analizlerine gübreleme programları düzenlenmeli ve yaprak analizleri de dikkate alınarak gübreleme önerilerinde bulunulmalıdır.

\section{Teşekkür}

$\mathrm{Bu}$ çalışmanın bir kısmı (Trabzon verileri) 21-22 Nisan 2018 tarihlerinde Mardin'de düzenlenen "EJONS International Congress on Mathematic, Engineering and Natural Sciences-III" kongresinde sözlü bildiri olarak sunulmuş olup, adı geçen kongre bildiriler kitabında özet metni yayınlanmıştır.

\section{Kaynakça}

Abd El-Latif, K. M., Osman, E. A. M., Abdullah, R., \& Abd El Kader, N. (2011). Response of potato plants to potassium fertilizer rates and soil moisture deficit. Advances in Applied Science Research, 2(2), 388-397.
Akça, H., Taban, N., Turan, M. A., Taban, S., Ouedraogo, A. R., \& Türkmen, N. (2017). Türkiye'de sarımsak tarımı yapılan toprakların verimlilik durumu. Toprak Bilimi ve Bitki Besleme Dergisi, 5(2), 93-100.

Akpınar, M., Şahin, C. B., \& İşler, N. (2019). Çukurova koşullarında turfanda patates yetiştiriciliğinde farklı azot dozlarının verim ve tarımsal özelliklere etkileri. Mustafa Kemal Üniversitesi Tarım Bilimleri Dergisi, 24(1), 37-42.

Al Fadlly, J. T. M., Khudhair, M. F., Wheib, K. A., \& Abd, W. M. (2020). Response of some vegetative growth characteristics of organically fertilized potatoes to zinc and manganese foliar application. Plant Archives, 20(Supplement 1), 1263-1266.

Al-Fadhly, J. T. M. (2016). Response of potato (Solanum tuberosum) to foliar application of zinc and manganese which fertilized by organic fertilizer. Journal of Agriculture and Veterinary Science, 9(4), I, 87-91.

Allison, M. F., Fowler, J. H., \& Allen, E. J. (2001). Effects of soil-and foliar-applied phosphorus fertilizers on the potato (Solanum tuberosum) crop. The Journal of Agricultural Science, 137(4), 379-395.

Anonymous. (1951). Soli Survey Staff, Soil Survey Manuel, Agricultural Research Administration U.S. Department of Agriculture Handbook No.18, Gount Point Office, Washington, pp. 340-377.

Anonymous. (1990). Micronutrient, Assessment at the Country Level: An International Study. FAO, Soils Bulletin by Mikko Sillanpaa, Rome.

Anonymous. (1992). Soil Survey Staff, Procedures for Collecting Soil Samples and Methods of Analysis for Soil Survey. Soil Survey Invest. Rep. I. U.S. Gov. Print. Office, Washington, D.C.

Anonymous. (2020a). International Year of the Potato, Cultivation. (http://www.fao.org/potato2008/en/potato/cultivation.html), (Erişim tarihi: 01.05.2020).

Anonymous. (2020b). Crop Guide: Potato Nutritional Requirements. (https://www.haifa-group.com/cropguide/field-crops/crop-guide-potato/nutrients-growingpotatoes), (Erişim tarihi: 03.05.2020).

Anonymous. (2020c). Role of Phosphate in Potato Production. (http://www.yara.us/agriculture/crops/potato/key-facts/roleof-phosphate/), (Erişim tarihi: 25.06.2020).

Bagherzadeh, A., Gholizadeh, A., \& Keshavarzi, A. (2018). Assessment of soil fertility index for potato production using integrated Fuzzy and AHP approaches, Northeast of Iran. 
Eurasian Journal of Soil Science, 7(3), 203-212.

Başaran, M., \& Okant, M. (2005). Bazı toprak özelliklerinin eldivan yöresinde yetiştirilen kirazların beslenme durumu üzerine etkisi. Tarım Bilimleri Dergisi, 11(2), 115-119.

Belachew, B. (2016). Effect of nitrogen and phosphorus rates on growth, yield, yield components and quality of potato (Solanum tuberosum L.) at dedo, South West Ethiopia. (M. Sc Thesis), Presented to School of Graduate Study of Jimma University, Ethiopia.

Bilen, S., \& Sezen, Y. (1993). Toprak reaksiyonunun bitki besin elementleri elverişliliği üzerine etkisi, I. Azot, fosfor ve potasyum. Atatürk Üniversitesi Ziraat Fakültesi Dergisi, 24(2), 156-166.

Bouyoucos, G. J. (1951). A Recalibration of the hydrometer method for making mechanical analysis of soil. Agronomy Journal, 43, 434-438.

Bray, R. H., \& Kurtz, L. T. (1945). Determination of total, organic, and available forms of phosphorus in soils. Soil Sci., 59, 39-45.

Burton, W. G. (1989). The Potato (Third edition). Longman Scientific \& Technical, London, UK, p.742.

Çağlar, K. Ö. (1949). Toprak Bilgisi. Ankara Üniversitesi, Ziraat Fakültesi Yayınları No: 10, Ankara.

Çelik, H., \& Urhan, G. (2020). Keles yöresi kiraz bahçelerinin beslenme durumlarının toprak, yaprak ve meyve analizleri ile değerlendirilmesi. Bursa Uludağ Üniversitesi Ziraat Fakültesi Dergisi, 34(1), 185-200.

Çetin, E., \& Eraslan, F. (2015). Afyonkarahisar ili Dinar ilçesi patates ekim alanlarında toprakların verimliliği ve bitkilerin beslenme durumlarının belirlenmesi. Süleyman Demirel Üniversitesi Ziraat Fakültesi Dergisi, 10(2), 135-145.

Demir, M., \& Çalışkan, S. (2017). Patateste (Solanum tuberosum L.) demir gübrelemesinin bitki gelişimi ve yumru verimi üzerine etkileri. KSÜ Doğa Bil. Derg., 20(Özel Say1), 241245.

Doğan, A., \& Erdal, İ. (2018). Burdur ili tahıl yetiştirilen toprakların verimlilik durumlarının belirlenmesi. Toprak Bilimi ve Bitki Besleme Dergisi, 6(1), 39-45.

Eren, A. (2019). Kızıltepe yöresinde buğday tarımı yapılan toprakların bazı verimlilik durumlarının belirlenmesi. Gaziosmanpaşa Bilimsel Araştırma Dergisi (GBAD), 8(1), 1-9.

Esendal, E. (1990). Nişasta Şeker Bitkileri ve Islahı, Cilt: 1, Patates. Ondokuz Mayıs Üniversitesi Yayınları, Yayın No: 49, Samsun, 221s.

Everest, T., Sungur, A., \& Özcan, H. (2020). Gelibolu Namaztepe bölgesindeki farklı fizyografyalar üzerindeki toprakların bazı fiziko-kimyasal özellikleri ve sinıflandirılması. ÇOMÜ LJAR, 1(1), 1-12.

Fernandes, A. M., Soratto, R. P., Moreno, L. D. A., \& Evangelista, R. M. (2015). Effect of phosphorus nutrition on quality of fresh tuber of potato cultivars. Bragantia, 74(1), 102-109.

İncekara, F. (1973). Endüstri Bitkileri ve Islahı. Cilt 3, NişastaŞeker Bitkileri ve Islahı (2. Baskı). Ege Üniversitesi Ziraat Fakültesi Yayınları, Yayın No: 101, Ege Üniversitesi Matbaas1, Bornova.

Jackson, M. L. (1958). Soil Chemical Analysis. Englewood Cliffs, NJ: Prentice- Hall. Inc.

Jane, M. (2016). Soil fertility situation in potato producing Kenyan Highlands - Case of KALRO-Tigoni. International Journal of Horticulture, 6(24), 1-11.

Janssens, S. R. M., Wiersema, S. G., Goos, H., \& Wiersma, W.
(2013). The Value Chain for Seed and Ware Potatoes in Kenya; Opportunities for Development. LEI Wageningen UR, Den Haag, The Netherlands.

Kanyanjua, S. M., \& Agaya, G. O. (2006). A Guide to Choice of Mineral Fertilizers in Kenya. KARI Technical Note No. 17, KARI, Nairobi, Kenya.

Kars, N., \& Ekberli, İ. (2019). Çarşamba Ovası'nda işlenen tarım alanlarının bazı fiziksel ve kimyasal toprak özelliklerinin incelenmesi. Anadolu Tarım Bilimleri Dergisi, 34, 210-219.

Kars, N., \& Ekberli, İ. (2020). Çarşamba Ovası'nda soya yetiştirilen tarım alanlarının verimlilik durumlarının belirlenmesi. Toprak Bilimi ve Bitki Besleme Dergisi, 8(1), 14-25.

Kavurmacı, Z. (2008). Değişik azot ve fosfor dozları ile pir öldürme ve hasat zamanlarının patatesin (Solanum tuberosum L.) verim ve verim unsurları üzerine etkisi. (Doktora tezi), Atatürk Üniversitesi, Fen Bilimleri Enstitüsü, Erzurum, Türkiye.

Khan, A. A., Jilani, M. S., Khan, M. Q., \& Zubair, M. (2011). Effect of seasonal variation on tuber bulking rate of potato. The Journal of Animal and Plant Sciences, 21(1), 31-37.

Kiiya, W. W., Mureithi, J. G., \& Kiama, J. M. (2006). Improving production of irish potato (Solanum tuberosum L.) in Kenya: The use of green manure legumes for soil fertility Improvement. In J. G. Mureithi et al. (Eds.), Development and up scaling of green manure legumes technologies in Kenya, KARI, Nairobi, Kenya.

Koch, M., Naumann, M., Pawelzik, E., Gransee, A., \& Thiel, H. (2020). The importance of nutrient management for potato production part I: Plant nutrition and yield. Potato Research, 63, 97-119.

Lenka, B., Divya, R. K., \& Das, S. K. (2020). Nutrient use effeciency, yield attributes and comparative economics of potato crop (Solanum tuberosum L.) in response to zinc and boron nutrition in entisols of India. International Journal of Chemical Studies, 8(3), 10-17.

Lindsay, W. L., \& Norvell, W. A. (1969). Development of a DTPA Micronutrient Soil Test. Soil Sci. Am. Proc., 35, 600602.

Lindsay, W. L., \& Norvell, W. A. (1978). Development of a DTPA soil test for zinc, iron, manganese and copper. Soil Sci. Soc. Am. J., 42(3), 421-428.

Loue, A. T. (1968). Diagnostic Petiolaire des Prospectian Etudes sur la Nutrition at la Fertilization Potassiques de la Vigne. Societe Commerciale des Potasses d'Alsace. Services Agronomiques, pp. 31-41.

Metcalfe, D. S., \& Elkins, D. M. (1980). Crop Production, Principles and Practices. Macmillian Publishing Co., Inc. New York.

Moinuddin, S. J., Sarkar, A., \& Dasgupta, S. (2017). Response of potato (Solanum tuberosum L.) to foliar application of macro and micronutrients in the Red and Lateritic Zone of West Bengal. Journal of Crop and Weed., 13(1), 185-188.

Mugo, J. N., Karanja, N. N., Gachene, C. K., Dittert, K., Nyawade, S. O., \& Schulte-Geldermann, E. (2020). Assessment of soil fertility and potato crop nutrient status in central and eastern highlands of Kenya. Natureresearch Scientific Reports, 10, 7779.

Muleta, H. D., \& Aga, M. C. (2019). Role of nitrogen on potato production: A review. Journal of Plant Sciences, 7(2), 36-42.

Muthanna, M. A., Singh, A. K., Tiwari, A., Jain, V. K., \& Padhi, M. (2017). Effect of boron and sulphur application on plant 
growth and yield attributes of potato (Solanum tuberosum L.). International Journal of Current Microbiology and Applied Sciences, 6(10), 399-404.

Nelson, D. W., \& Sommers, L. E. (1982). Total Carbon, Organic Carbon, and Organic Matter. In: A.L. Page (Ed.), Methods of Soil Analysis: Part 2, Chemical and Microbiological Properties, 9.2.2, Second Edition, Wisconsin, American Society of Agronomy Inc., USA, pp. 539-579.

Olsen, S. R., Cole, C. V., Watanabe, F. S., \& Dean, L. A. (1954). Estimation of Available Phosphorus in Soils by Extraction with Sodium Bicarbonate. USDA Circular No. 939, U.S. Government Printing Office, Washington, D.C.

Ordu, D. (2020). Bursa ili Karacabey ilçesi mısır tarımı yapılan toprakların (Yolağzı bölgesi) verimlilik durumunun belirlenmesi. (Yüksek lisans tezi), Bursa Uludağ Üniversitesi, Fen Bilimleri Enstitüsü, Bursa, Türkiye.

Özkutlu, F., Ete Aydemir, Ö., Akgün, M., \& Özcan, B. (2019). Ordu ilinde findık (Corylus avellana L.) tarımı yapılan toprakların çinko ( $\mathrm{Zn}$ ) beslenme durumu ve potansiyel beslenme problemlerinin belirlenmesi. Akademik Ziraat Dergisi, 8(Özel Say1), 131-140.

Özyazıc1, M. A., Dengiz, O., \& Sağlam, M., 2013. Artvin ilinde yonca (Medicago sativa L.) tarımı yapılan toprakların verimlilik durumu ve potansiyel beslenme problemlerinin ortaya konulması. Artvin Çoruh Üniversitesi Orman Fakültesi Dergisi, 14(2), 225-238.

Özyazıc1, M. A., Dengiz, O., Aydoğan, M., Bayraklı, B., Kesim, E., Urla, Ö., Yıldız, H., \& Ünal, E. (2016). Orta ve Doğu Karadeniz Bölgesi tarım topraklarının temel verimlilik düzeyleri ve alansal dağılımları. Anadolu Tarım Bilimleri Dergisi, 31(1), 136-148.

Parlak, M. (2016). İzmir ili Ödemiş ilçesi'nde patates yetiştirilen toprakların verimlilik durumlarının belirlenmesi. Ege Üniversitesi Ziraat Fakültesi Dergisi, 53(3), 325-331.

Pizer, N. H. (1967). Some Advisory Aspect. Soil Potassium and Magnesium. Tech. Bull. No.14, 184.

Recke, H., Schnier, H. F., Nabwile, S., \& Qureshi, J. N. (1997). Responses of irish potatoes (Solanum tuberosum L.) to mineral and organic fertilizer in various agro-ecological environments in Kenya. Experimetal Agriculture, 33, 91-102.

Richards, L. A. (1954). Diagnosis and Improvoment of Saline and Alkaline Soils. U.S.A: U.S. Department of Agriculture, Handbook 60.

Rourke, R. V. (1985). Soil solution levels of nitrate in a potatobuckwheat rotation. American Potato Journal, 62, 1-8.

Sağlam, M. T. (1978). Toprak Kimyası Tatbikat Notları. Atatürk Üniversitesi Ziraat Fakültesi Toprak Bölümü, Erzurum.

Sarkar, D., Mandal, B., \& Kundu, M. C. (2007). Increasing use efficiency of boron fertilisers by rescheduling the time and methods of application for crops in India. Plant Soil, 301, $77-$ 85.

Taban, S., Alpaslan, M., Hashemi, A. G., \& Eken, D. (1997). Orta Anadolu'da çeltik tarımı yapılan toprakların bazı fiziksel ve kimyasal özellikleri. Pamukkale Üniversitesi Mühendislik Fakültesi Mühendislik Bilimleri Dergisi, 3(3), 457-466.

Tatar, E. (2019). Farklı potasyum ve fosfor dozlarının patates'te (Solanum tuberosum L.) verim ve verim unsurlar1 üzerine etkilerinin belirlenmesi. (Yüksek lisans tezi), Ordu Üniversitesi, Fen Bilimleri Enstitüsü, Ordu, Türkiye.

Tindall, T. A., Westermann, D. T., Stark, J. C., Ojala, J. C., \& Kleinkopf, G. E. (1993). Phosphorus Nutrition of Potatoes. University of Idaho, College of Agriculture, Cooperative Extension System, Current Information Series No. 903. (http://eprints.nwisrl.ars.usda.gov/1166/1/802.pdf.), (Erişim tarihi: 23.06.2020).

Trehan, S. P., \& Grewal, J.S. (1981). Comparitive efficiency of methods of application of Zinc to potato. Ind. J. Agric. Sci., 51, 240-243.

Tunçtürk, M., Erman, M., \& Tunçtürk, R. (2004). Patates (Solanum tuberosum L.) çeşitlerinde fosforlu gübre uygulamalarının verim ve bazı verim öğelerine etkisi. Ankara Üniversitesi Ziraat Fakültesi Dergisi, 10(4), 466473.

Ülgen, N., \& Yurtsever, N. (1995). Türkiye Gübre ve Gübreleme Rehberi (4. Bask1). T.C. Başbakanlık Köy Hizmetleri Genel Müdürlüğü Toprak ve Gübre Araştırma Enstitüsü Müdürlüğü Yayınları, Genel Yayın No: 209, Teknik Yayınlar No: T.66, Ankara, 230s.

Westermann, D. T., Kleinkopf, G. E., \& Porter, L. K. (1988). Nitrogen fertilizer efficiencies on potatoes. American Potato Journal, 65, 377-386.

Wolf, B. (1971). The determination of boron in soil extracts, plant materials, composts, manures, water and nutrient solutions. Soil Science and Plant Analysis, 2(5), 363-374.

Yağmur, B., \& Okur, B. (2011). İzmir kemalpaşa ilçesi kiraz bahçelerinin verimlilik durumları ve ağır metal içerikleri. Batı Akdeniz Tarımsal Araştırma Enstitüsü Derim Dergisi, 28(2), 1-13

Zelalem, A., Tekalign, T., \& Nigussie, D. (2009). Response of potato (Solanum tuberosum L.) to different rates of nitrogen and phosphorus fertilization on vertisols at Debre Berhan, in the central highlands of Ethiopia. African Journal of Plant Science, 3(2), 016-024.

Zhang, W., Liu, X., Wang, Q., Zhang, H., Li, M., Song, B., \& Zhao, Z. (2018). Effects of potassium fertilization on potato starch physicochemical properties. International Journal of Biological Macromolecules, 117, 467-472. 